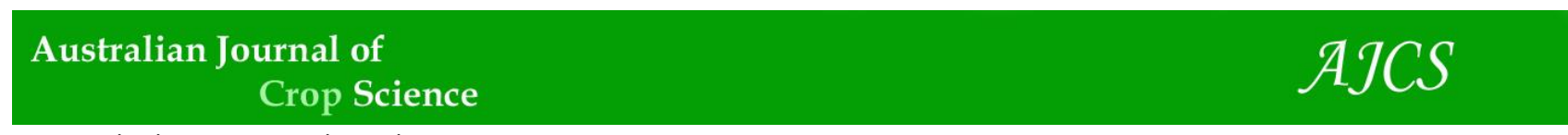

AJCS 11(08):1068-1077 (2017)

ISSN:1835-2707

doi: 10.21475/ajcs.17.11.08.pne653

\title{
Low water input confers sustainable rice production without affecting soil, plant physiological and yields parameters
}

\author{
Mohd Khairi ${ }^{1}$, Syed Ahmad Naqib ${ }^{1}$, Md. Mainul Hasan ${ }^{2}$, Md. Sarwar Jahan ${ }^{1 *}$ \\ ${ }^{1}$ Faculty of Bioresources and Food Industry, Universiti Sultan Zainal Abidin, Besut, Terengganu, 22200 Malaysia \\ ${ }^{2}$ Department of Agricultural Botany, Faculty of Agriculture, Patuakhali Science and Technology University, \\ Dumki, Patuakhali, 8602 Bangladesh
}

\section{*Corresponding author: sarwarjahan@unisza.edu.my}

\begin{abstract}
The demand for fresh water is increasing progressively for the use of the community and during crop production. An experiment was conducted to investigate the effect of low water input (LWI) on soil health, and crop yield. Soil chemical properties, physiological and yield parameters of rice plants which were grown under different water input treatments were examined. The treatments were as W1 (control; $5 \mathrm{~cm}$ flooding), W2 (1 cm flooding), W3 (saturated condition) and W4 (field capacity). Treatments were arranged according to the completely randomized design with five replications. The result revealed that LWI (e.g. saturation and $1 \mathrm{~cm}$ flooding) did not affect phytoavailability of nutrients in soil compared to the control. However, concentrations of nutrients such as nitrogen calcium, potassium, magnesium, cupper and manganese decreased with increasing plant age regardless of treatments except for phosphorus, zinc and iron. The redox potential (Eh) decreased significantly in control treatment than low water input condition. The soil pH showed moderately acidic to near neutral whilst the soil electrical conductivity (EC) remained same. The W4 treatment significantly reduced relative water content (RWC), light- and gas exchange-related parameters, yield parameters, harvest index (HI) and water use efficiency (WUE) compared to the LWI and control. This study suggests that low water input sustains rice production without affecting the soil health, physiological and yield parameters of rice plants.
\end{abstract}

Keywords: Low water input, Soil health, Nutrients, Physiology and Yield of rice.

Abbreviation: Chl_chlorophyll; DW_dry weight; EC electrical conductivity; Eh_redox potential; FW_fresh weight; HI_harvest index; Fv / Fm _quantum yield; int_ $\mathrm{CO}_{2}$ internal $\mathrm{CO}_{2}$; $\mathrm{LWI}$ low water input; qp and ql_coefficients of photochemical fluorescence quenching; NPQ and qn_parameters of non-photochemical quenching; RWC_relative water content; TW_turgid weight; WUE_water use efficiency; Y(NO)_the yield of non-regulated energy dissipation of PSII; Y(II)_the value of the efficient quantum yield of PSII; $\mathrm{Y}(\mathrm{NPQ})\}_{-}$yield of regulated energy dissipation of PSII.

\section{Introduction}

Rice cultivation takes ample of fresh water to provide food security to billions of people. A recent scenario shows that diets shifting from starch-based to meat and dairy products requires a higher amount of fresh water over the past 30 years and is likely to be continued (FAO, 2006). On average, for producing $1 \mathrm{~kg}$ of rice, $1 \mathrm{~kg}$ of beef and a cup of coffee need 3,500, 15,000, and $140 \mathrm{~L}$ of water, respectively (Hoekstra and Chapagain, 2008). Agriculture accounts about $70 \%$ of global freshwater withdrawals. Reducing about $10 \%$ of water used for world's rice production could free up to 100 cubic kilometers of water to be provided for a half to a quarter of the world's population (Bouman, 2012). In addition, population growth results in food demand about $50 \%$ and declined water availability in many regions (Bruinsma, 2009). It is, therefore, important to focus on the innovative water use for sustainable rice production. The hydrological-cycle changes increase water scarcity (Goudie, 2006), which become an ever-increasing problem in the modern agriculture. Drought controls precipitation and leads the inconsistency water resources worldwide (Oki et al., 2006). In Asia, irrigated rice accounts $50 \%$ of the total freshwater used (IRRI, 2001). Low water input in the rice production did not affect rice yield but saved approximately
$1 / 4$ of fresh water used in traditional irrigation system (Sarwar and Khanif, 2005a; Khairi et al., 2015). In Malaysia, the current annual water demand increases at $4 \%$, which will requisite about 20 billion $\mathrm{m}^{3}$ by 2020 but current rice production covers only $70 \%$ of the country's demand (Keizrul and Azuhan, 1998; Ariffin, 1998). Therefore, low water input and sustainable rice production without affecting soil and plant parameters is under pressure. The concentration of water-soluble $\mathrm{Fe}$ (II) increased in the flooded soil due to reduction to Fe (II). Soil pH affects and controls $\mathrm{Fe}$ and $\mathrm{Mn}$ concentration in the flooded rice soil (Ponnamperuma et al., 1973). The redox potential (Eh) of flooded rice soil is low and $\mathrm{NO}^{3-}, \mathrm{Fe}^{3+}, \mathrm{Mn}^{4+}$, and $\mathrm{SO}_{4}{ }^{2-}$ reduced to $\mathrm{NH}^{4+}, \mathrm{Fe}^{2+}, \mathrm{Mn}^{2+}$, and $\mathrm{S}^{2-}$ (Fan et al., 2008). The flooding condition increases the availability of phosphorus (Gupta et al., 2007, Jahan, 2016) and controls soil pH, chemical equilibrium and induce the phytoavailability of plant nutrients (Morales et al., 2011; Jahan, 2016). The influences of flooding on physical, chemical and electrochemical properties of the soil were comprehensively documented and reviewed (Narteh and Sahrawat, 1999; De Datta, 1981). Flooded triggers oxygen reduction in flooded soil that causes anaerobiosis (Narteh and Sahrawat, 1999) 
that decreases Eh to about $-200 \mathrm{mV}$ compared to the top soil which remains relatively oxidized to a value of about +300 $\mathrm{mV}$ (Ponnamperuma, 1972). On the other hand, the availability of free water improves phytoavailability and accessibility of nutrients (Sarwar et al., 2004) through diffusion and mass flow to the plant roots (Ponnamperuma, 1984).

Rice plants sensitive to the drought condition and incompetent to regulate transpirational functions (Bois et al., 1985). Low water reduces tissue water potential (Kato et al., 2004) and net photosynthesis rate (Khairi et al., 2015; Inani et al., 2015). Glutathione, an antioxidant, enhanced chlorophyll pigment that works well in photosystem II (Jahan et al., 2016), and increases the net photosynthesis rate and relative water content of leaves of corn plants (Syuhada et al., 2016; Munirah et al., 2015a). The quantum yield (Fv/Fm ratio) in PSII shows the efficiency of light function that controls the chlorophyll content in corn plants (Jahan et al., 2014). Sheela and Alexander (1996) stated that water stress limits chlorophyll contents in leaves of rice plants. Other researchers reported that drought stress reduced chlorophyll content, the photosynthetic units in Zea mays (Randall et al., 1977) and rice plants (Khairi et al., 2015). These results indicate that the loss of chlorophyll is a fundamental basis of disrupting of the photosynthesis rate in plants (Kura-Hotta et al., 1987) to affect rice production.

To date, many types of researches have been conducted to find out the way to reduce water input in rice cultivation but attention yet to be paid on the effects of low water input on phytoavailability of nutrients in soil concerning to physiological properties of the rice plants. The rice production, therefore, depends on the innovation and practices that will ensure low water input but sustainable rice production.

\section{Result}

\section{Effects of different water inputs on phytoavailability of} macronutrients

Different water inputs did not affect ammonium $\left(\mathrm{NH}_{4}{ }^{+}\right)$ concentrations except at $3^{\text {rd }}$ and $5^{\text {th }}$ week under which W4 treatment significantly reduced $\mathrm{NH}_{4}{ }^{+}$concentration than other treatments (Fig. 1a). The concentrations of $\mathrm{NH}_{4}{ }^{+}$increased after flooding then decreased gradually with time and irrespective of the application of urea and compound fertilizers (Fig. 1a). The concentrations of phosphorus (P) dropped for the first few weeks followed by increment for the following weeks under different water input conditions (Fig. 1b). But when $\mathrm{P}$ concentrations were compared among treatments, W4 treatment showed lower concentration than others. The $\mathrm{K}$ concentrations increased after flooding then a rapid declined from $5^{\text {th }}$ to $7^{\text {th }}$ week then remained unchanged for subsequent weeks (Fig. 1c). Moreover, W4 treatment significantly reduced $\mathrm{K}$ concentrations in the soil solution after flooding compared to other treatments (Fig. 1c). Calcium (Ca) contents decreased after flooding then remained unchanged for the following weeks (Fig. 1d). Phytoavailability of $\mathrm{Mg}$ was similar to the Ca concentration. But $\mathrm{Mg}$ concentration was higher than that of $\mathrm{Ca}$ concentration in soil (Fig. 1e). This result showed that low water input did not affect phytoavailability of macronutrients in the soil solution.

\section{Effects of different water inputs on phytoavailability of micronutrients}

Zinc $(\mathrm{Zn})$ concentration remains unchanged up to $7^{\text {th }}$ week then increased under all conditions (Fig. 2a). But W4 treatment lessened the concentrations of $\mathrm{Zn}$ than other treatments. Copper $(\mathrm{Cu})$ concentration, on the other hand, declined gradually with increasing time (Fig. 2b). However different water inputs did not affect $\mathrm{Cu}$ concentration. Iron (Fe) concentration gradually increased with increasing time until the ripening stage (Fig. 2c). After submergence, hydrated $\mathrm{Fe}^{3+}$ oxide is reduced to $\mathrm{Fe}^{2+}$ oxide (Ponnamporuma, 1977). The result was consistent with this study where application of water influences Fe contents in soil. Manganese (Mn) concentration increased after submergence then gradually declined to a stable level after $7^{\text {th }}$ week (Fig. 2d). Different water inputs showed similar effects on $\mathrm{Mn}$ contents in the soil extract. These results suggest that low water inputs do not affect phytoavailability of micronutrients in soil solution.

\section{Effects of different water levels on redox potential, soil pH and $E C$}

After flooding, the soil redox potential (Eh) decreased rapidly according to the flooding depths and duration (Fig. 3a). The Eh value showed more negative and significantly lower in the soil under W1 treatments than that of other treatments. The soil Eh value in W3 and W4 persisted positively higher than that of W1 and W2 treatments (Fig. 3a). In this relation, W1 treatment accounted redox value lower than $-150 \mathrm{mV}$ whereas $\mathrm{W} 3$ and $\mathrm{W} 4$ showed higher than $0 \mathrm{mV}$ throughout the rice growing period. At the flowering stage, Eh value positively increased due to application of $5 \mathrm{~cm}$ flooding water. These results suggest that control treatment (W1) turned soil to reduced condition than low water inputs (W2 and W3). However, different treatments did not affect soil $\mathrm{pH}$ and soil electrical conductivity over the rice-growing period (data not shown). The soil $\mathrm{pH}$ was found to be moderately acidic to the near neutral (soil $\mathrm{pH}$ : 6.0 to 6.5 ).

\section{Effect of different water inputs on chlorophyll and light-related parameters}

The W4 treatment significantly reduced chlorophyll content $(\mathrm{P}<0.032)$ in leaves of the rice plants compared to other treatments (Fig. 4a). Similarly, W4 treatment significantly affected Chlorophyll fluorescence parameters ( $\mathrm{P}<0.021$; F0: minimal fluorescence, Fm: maximal fluorescence and Fv / Fm: quantum yields in photosysthem II; (Fig. 4b). This study confirmed that LWI did not affect Chlorophyll content and Chlorophyll fluorescence (Fig. 4a and 4b) and showed similar compared to the control treatment but significantly higher than W4 treatment.

The data of the photochemical fluorescence quenching (qp and ql) showed similar but non-photochemical quenching (qn and NPQ) showed significantly different under different treatments (Fig. 4c and 4d, respectively). W1 treatment significantly increased but W4 treatment significantly decreased qn and NPQ value than other treatments. Whilst, W2 and W3 treatments showed similar results of qn and NPQ values but higher than $\mathrm{W} 4$ treatment. The yield of non-regulated energy dissipation of PSII [Y(NO)] under W4 treatment was 0.44 which was significantly higher than the value of 0.33 under W1 treatment (Fig. 4e). In contrast, W1, $\mathrm{W} 2$ and $\mathrm{W} 3$ treatments showed no effect on $\mathrm{Y}(\mathrm{NO})$, in rice 
plants. W4 treatment significantly reduced efficient quantum yield of PSII $\{\mathrm{Y}(\mathrm{II})\}$ and yield of regulated energy dissipation of PSII \{Y(NPQ) $\}$ than other treatments (Fig. 4e). The decreased value of Y(II) in plants might be a cause of a reduction of the quantum yield (Fig. 4b). These results suggest that low water inputs did not impair chlorophyll and light- related parameters of the rice plants.

\section{Effect of different water inputs on RWC, gas exchange and leaf temperature}

Different treatments significantly affected relative water content (RWC) in leaves of rice plants (Fig. 5a). The W4 treatment significantly reduced RWC compared to other treatments. This study also confirmed that W4 treatment affected RWC in leaves of the rice plants but LWI showed similar to the control. The int_ $\mathrm{CO}_{2}$ in leaves of rice plants under W4 treatments showed significantly lower than that of plants under other treatments (Fig. 5b). Similar to RWC, LWI did not affect int_ $\mathrm{CO}_{2}$ compared to the control treatment. The treatment of $\mathrm{W} 4$ significantly increased leaf temperature compared to other treatments (Fig. 5c). In addition, W3 treatment significant increased but W2 insignificantly different leaf temperature to the control treatment. This result revealed that the plants under LWI condition assimilated similar $\mathrm{CO}_{2}$ to the control as well as leaf temperature.

\section{Effects of low water inputs on yield and yield parameters}

Different water inputs significantly affected tiller and panicle numbers of the rice plants (Fig. 6a). The W4 treatment significantly reduced tiller and panicle numbers compared to other treatments. But, low water input did not affect tiller numbers compare to the control treatment. Plants suffer for the water stress that reduce filled grains and yield due to the dry condition of soil in treatment W4 (Fig. 6b). In contrast, LWI did not affect grain production and yield as compared to the control. Harvest index (HI) significantly reduced under W4 treatment compared to low water input, which showed similar to the control treatment (Fig. 6c). Water use efficiency (WUE) under low water input (W2 and W3) showed significantly higher than $\mathrm{W} 1$ and $\mathrm{W} 4$ treatments (Fig. 6c). This result suggests that low water input did not affect WUE of the rice plants.

\section{Discussion}

In Asia, agricultural development for several decades has focused on increasing of staple foods, e.g. rice, to eliminate food shortages. Technologies based on chemical fertilizers and high-yielding varieties have been successfully achieved. Beside on rapid industrial development, it still has to develop some alternative practices to reduce water input in rice cultivation for sustainable rice production.

\section{Chemical properties of the soil}

Nutrient availability in flooded soils is quite different from the non-flooded soil. Nitrate quickly denitrified in flooding soil (Ponnamperuma, 1972) and $\mathrm{NH}_{4}-\mathrm{N}$ is the largest source of the nitrogen for field crops (Godshalk and Wetzel, 1978). The amount of $\mathrm{N}$ accumulation in plants increased at vegetative stage but declined at ripening stage (Ishizuka, 1965; Yoshida, 1981). This finding supported this study that the phytoavailability of $\mathrm{N}$ in the soil solution was higher at early stage of rice plant and gradually decreases with increasing plant age (Fig. 1a). This result indicates that rice plants accumulated higher level of $\mathrm{N}$ at the vegetative stage, which was consistent with Jahan et al. (2012). Phytoavailability of phosphorus increases in flooded soil involves in the reduction of ferric $\left(\mathrm{Fe}^{3+}\right)$ phosphate to ferrous $\left(\mathrm{Fe}^{2+}\right)$ phosphate and hydrolysis of $\mathrm{AlPO}_{4}$ and reduction of $\mathrm{FePO}_{4}$ (Patrick and Mahapatra, 1968). In soil extract, the P concentration increased after flooding (Fig. 1b). These results support that temporary flooding increases $\mathrm{P}$ availability in soil and consistent with previous studies (Ishizuka, 1965; Thiyagarajan and Selvaraju, 2001; Sarwar et al., 2004). These results suggest that $\mathrm{P}$ availability is higher in flooded soil than that of upland soil. Potassium is displaced by $\mathrm{Fe}^{2+}$ and $\mathrm{NH}_{4}{ }^{+}$from exchange sites of the soil colloid in flooded soil (Ponnamperuma, 1972; De Datta and Mikkelsen, 1985). This leads to decrease $\mathrm{K}$ contents in flooded soil due to fixation, because, the plant-available $\mathrm{K}$ declines after the flooding of dry soil (Olk et al., 1995) which is consistent with Figure 1c and Ishizuka (1965) that K decreased gradually according to the growth of the rice plant.

Figure 2c indicates that $\mathrm{Fe}^{2+}$ concentration gradually increased in the soil solution with increasing time until the ripening stage, which is consistent with results that the iron content in the soil was $300 \mathrm{mg} / \mathrm{L}$ after submergence (Yoshida, 1981; Ponnamperuma et al., 1973). The phytoavailability of $\mathrm{Zn}$ in the soil solution was similar to Fe. The concentration of $\mathrm{Cu}$, and $\mathrm{Mn}$ decreased in the soil solution with increasing plant age. It is suggested that LWI did not affect phytoavailability of nutrients in contrast with the control in the soil solution (Sarwar and Khanif, 2005c).

Redox potential is a measure of oxidation-reduction status of the flooded soil. The redox potential has to be essentially below $-150 \mathrm{mV}$ to initiate $\mathrm{CH}_{4}$ production (Connell and Patrick, 1969). The result (Fig. 3a) revealed that the redox value was lower then $-250 \mathrm{mV}$ under control treatment but about $-150 \mathrm{mV}$ was under LWI condition, which is consistent with Hou et al. (2000). These results suggest that redox value strongly depends on the depth and duration of the standing water. In addition, LWI increased redox value, which might hinder $\mathrm{CH}_{4}$ productions according to $\mathrm{Yu}$ et al. (2001) and might enhance photosynthesis rate (Kim et al., 1999). Redox potential value about $-150 \mathrm{mV}$ under LWI indicates less possibility to induce methane gas according to Neue (1997). In addition, traditional flooding may reduce net photosynthesis activity due strongly reduced soil (Kim et al., 1999). Flooded rice fields are considered one of the most important sources of atmospheric $\mathrm{CH}_{4}$ enrichment. Significant $\mathrm{CH}_{4}$ formation in soils occurs when soil Eh declines below $-150 \mathrm{mV}$ (Connell and Patrick, 1969; Wang et al., 1993; Cicerone and Oremland, 1988).

\section{Light, gas and physiological parameters of rice plants}

Chlorophyll is the green pigment common to all photosynthetic cells by which phosphorylation process absorbs light energy to the chemical energy (Barber, 2006). This study confirmed that LWI did not affect Chl content and Chl fluorescence (Fig. 4a and $4 \mathrm{~b}$ ) and showed similar qn and NPQ; (Fig 4d) compared to the control treatment but significantly higher than W4 treatment. The light energy might be regulated by NPQ (Foyer and Harbinson, 1999). NPQ is a prominent prophylactic protection strategy for the light reaction of the photosynthetic electron pathway. In the light-harvesting complexes, NPQ scatters additional excitation energy by using xanthophylls and absorbance cross-section of the photosystems (Bailey et al., 2005). In addition, NPQ and photosynthesis showed a positive 

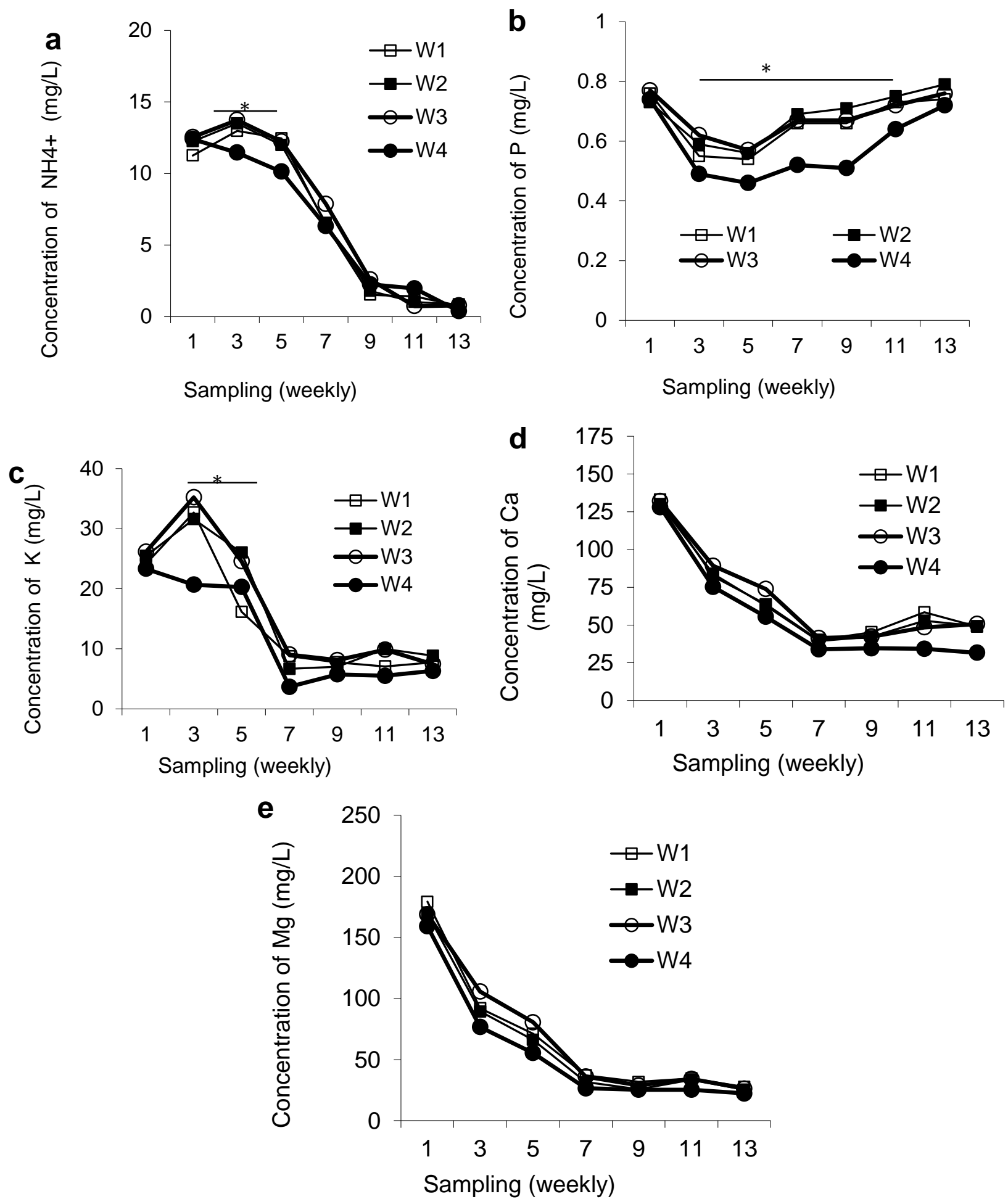

Fig 1. Effects of LWI on the phytoavailability of macronutrients in soil solution. The concentration of $\mathrm{NH}_{4}^{-}$(a), phosphorus (b), potassium (c), calcium (d) and magnesium (e) in the soil solution. 

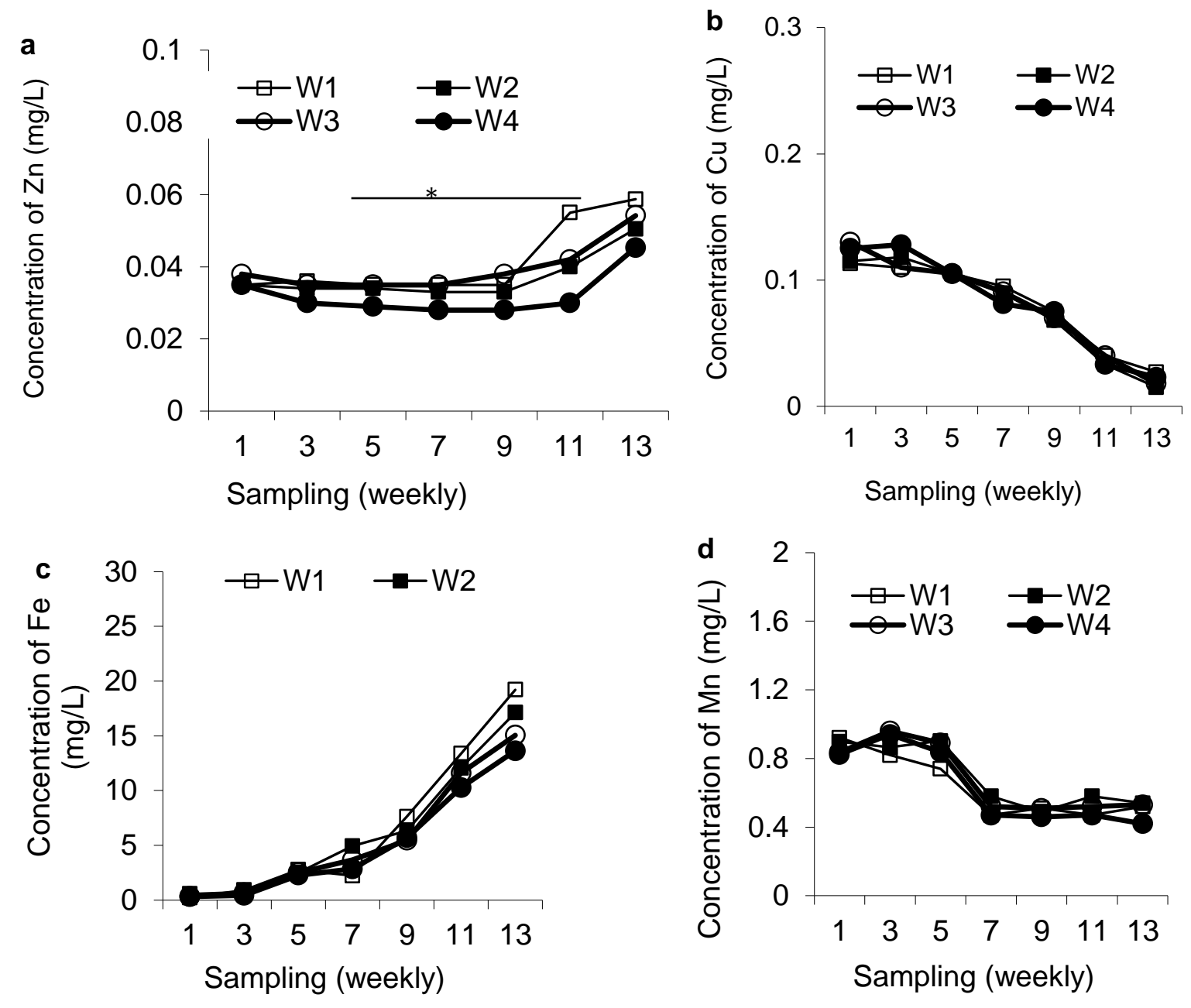

Fig 2. Fig 2. Effects of LWI on the phytoavailability of micronutrients in soil solution. The concentration of zinc (a), copper (b), iron (c) and manganese (d) in the soil solution.

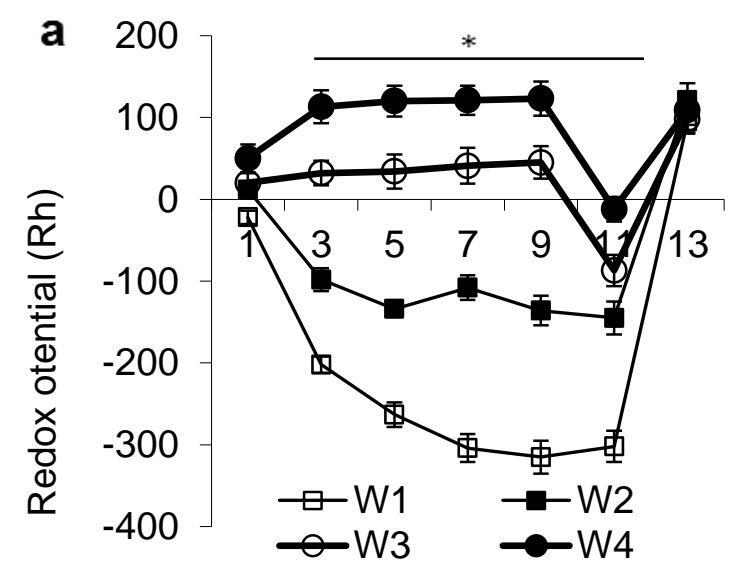

Sampling (weekly)

Fig 3. Effects of LWI on redox potential in soil. The asterisk with horizontal line shows significant $(\mathrm{P} \leq 0.05)$ difference between treatments. 

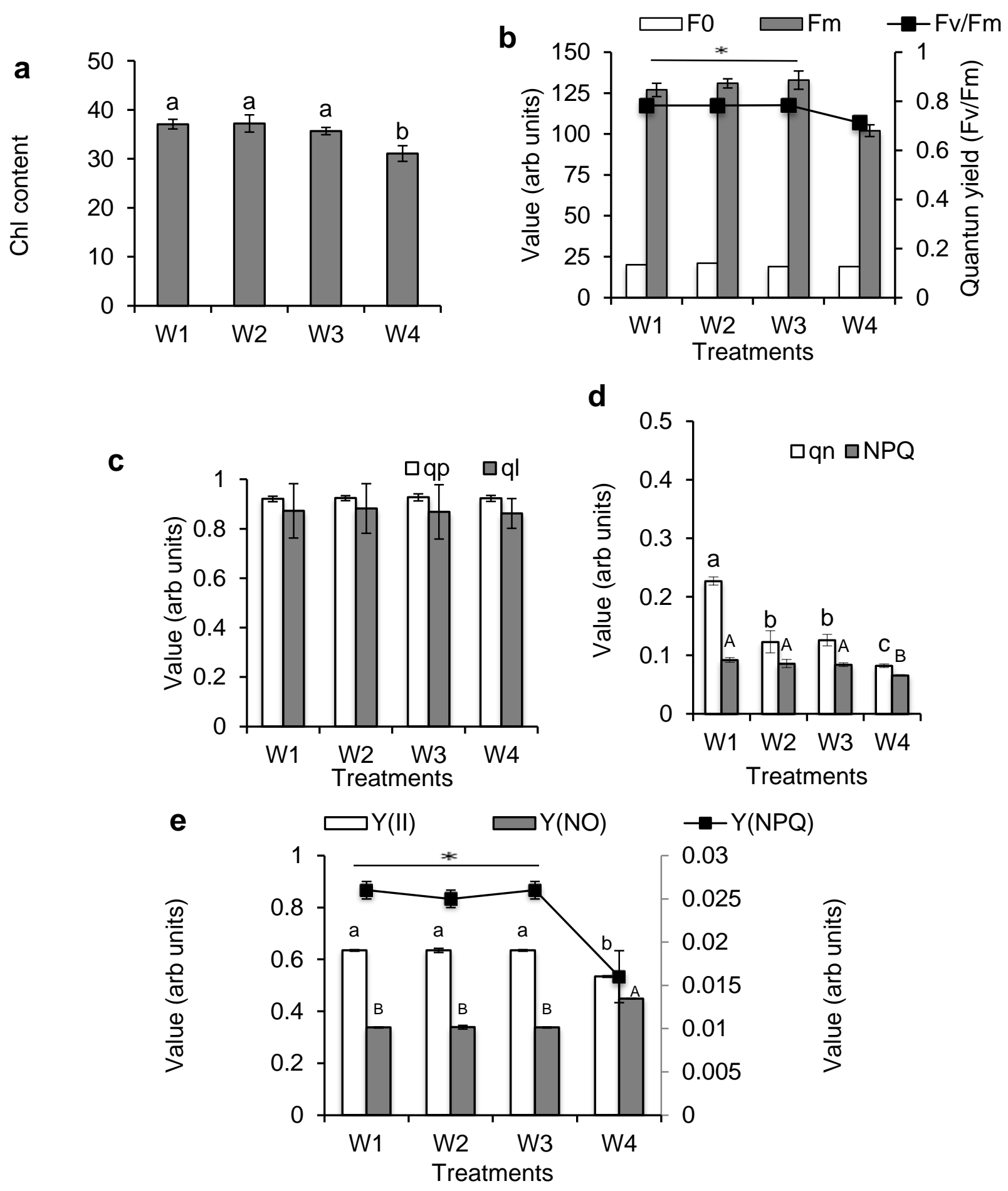

Fig 4. Effects of LWI on light related parameters in leaves of rice plants. a, Chl content in leaves of rice plants. b, Chl fluorescence in leaves of rice plants where F0; minimal, Fm; maximal and Fv / Fm; quantum yield. c, qp and ql in leaves of rice plants. d, qn and NPQ in leaves of rice plants. e, $Y(N O), Y(I I)$ and $Y(N P Q)$ in leaves of rice plants. 


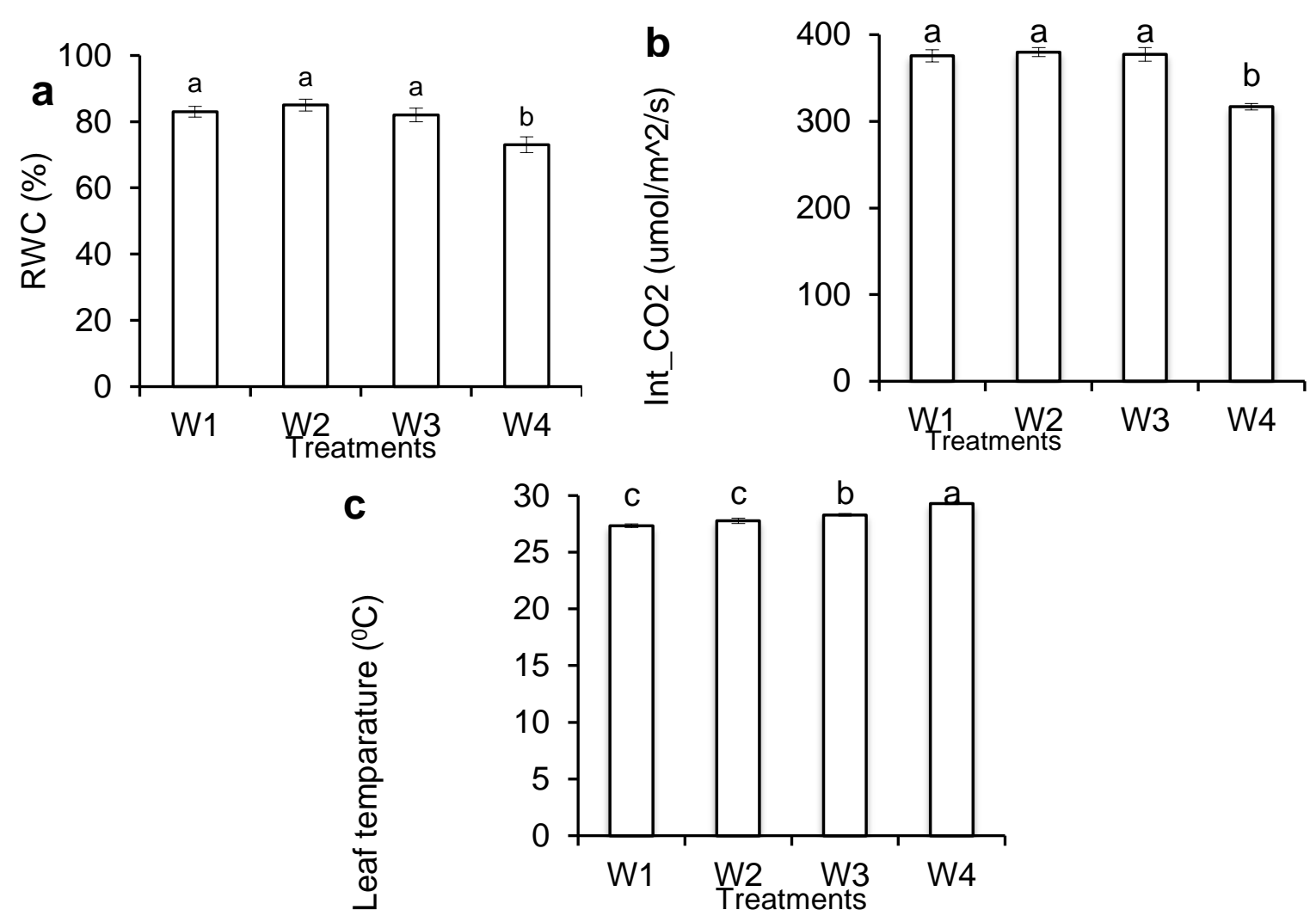

Fig 5. Effects of LWI on RWC (a), Int_CO $\mathrm{CO}_{2}$, stomatal conductance (b) and leaf temperature (c) in leaves of the rice plants.

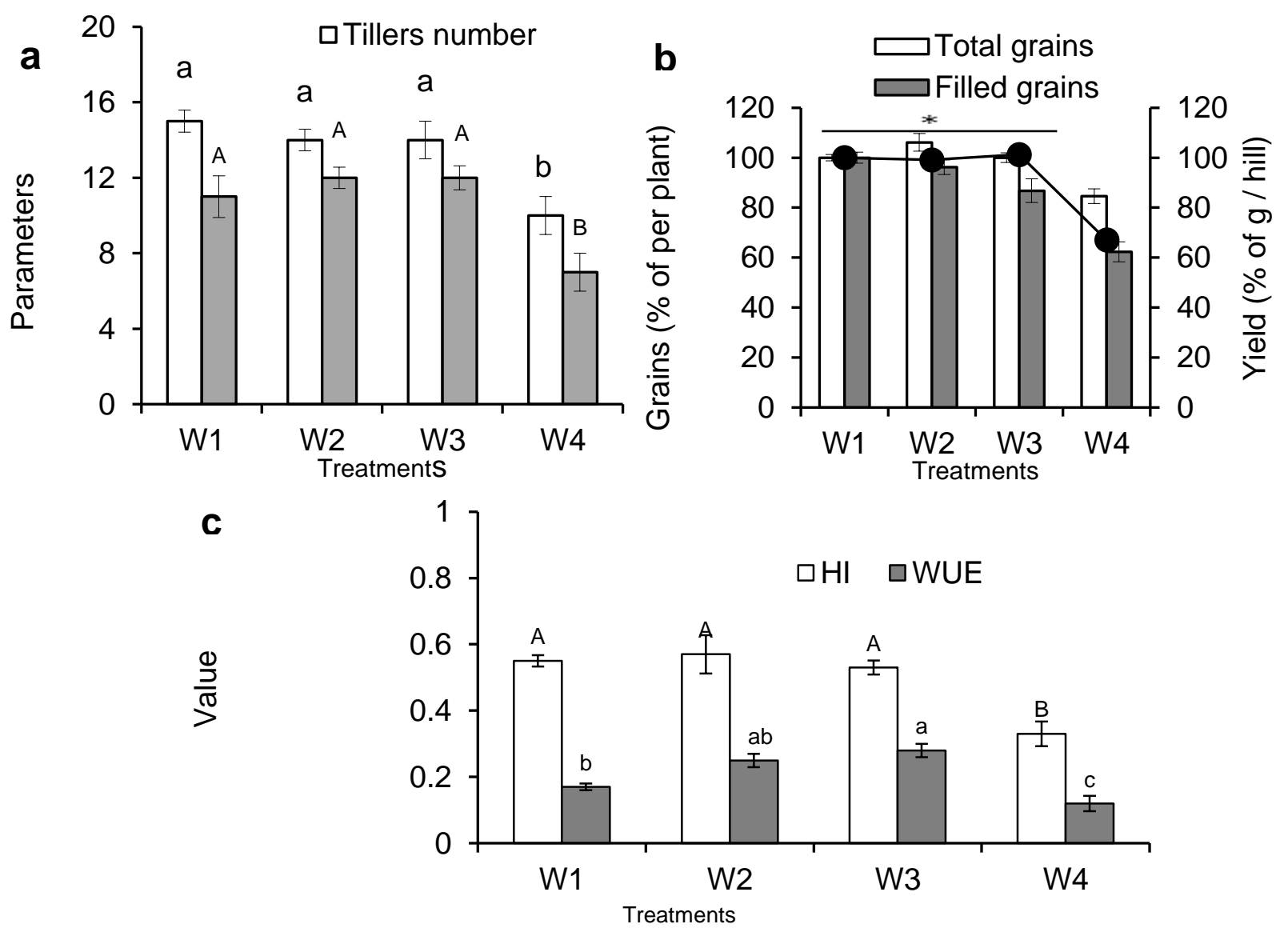

Fig 6. Effects of LWI on yield and yield parameters of rice plants. a, tillers number (open bars) and panicles number (closed bars) per pot. b, total grains per panicle (open bars), filled grains per panicle (closed bars) and yield per pot (close round) of rice plants. c, harvest index (open bars) and water use efficiency (close bars) of rice plant per pots. 
relationship (Schubert et al., 2006). Therefore, rice plants under W4 treatment accumulated lower quantity of Y(II), and $\mathrm{Y}(\mathrm{NPQ})$ but higher quantity of $\mathrm{Y}(\mathrm{NO})$ than other treatments (Fig. 4e). These results are related to the fact that water stress condition affects light energy and reduced the qn and NPQ in rice plants (Fig 4d) which is related to the photosynthesis (Müller et al., 2004) and Chl-regulated glutathione biosynthesis in plants (Jahan et al., 2016). Therefore, this result recommends that LWI regulates $\mathrm{Chl}$ and light related parameters of rice plant similar to the control condition.

Several researches indicated that the soil amendments (Chelah et al., 2011), micronutrients (Inani et al., 2015; Munirah et al., 2015a; Syuhada et al., 2014), water stress (Jahan et al., 2013a and b; Khairi et al., 2015), glutathione (Munirah et al., 2015b; Syuhada et al., 2016) affects the RWC of leaves of the plants. This study also confirmed that W4 treatment affected RWC content in leaves of the rice plants (Fig. 5a) but LWI showed similar to the control. Therefore, LWI did not affect RWC and might not photosynthesis rate (Kura-Hotta et al., 1987). This result was consistent with this study that the plants under LWI condition assimilated similar int_ $\mathrm{CO}_{2}$ to the control (Fig. 5b) as well as leaf temperature (Fig. 5c). Because water stress enhanced stomatal closure (Okuma et al., 2011; Jahan et al., 2008), which reduced the transpirational water loss (Vandeleur et al., 2009) and tissue water potential in plants (Kato et al., 2004). This result indicates that LWI might not affect stomatal aperture and tissue water content therefore leaves of rice plants keep similar temperature to the control condition (Fig. 5c). Taken together, LWI did not affect RWC and gas exchange through the leaf of rice plants and maintained normal growth and development.

\section{Yield and yield components of rice plants}

Rice grows in a wide range of water conditions, soil types and climates. A conventional flooded system used in Malaysia that leads using a larger amount of fresh water (Khairi et al., 2015; Jahan, 2016). Different water inputs significantly affected tiller and panicle numbers of the rice plants (Fig. 6a). Plants suffer for the water stress that reduce filled grains and yield due to the dry condition of soil in treatment W4 (Fig. 6b). In contrast, LWI did not affect grain production and yield as compared to the control (Fig. 6b). These results were supported by the previous results (Sariam et al., 2002; Sarwar et al., 2004) that saturated to $1 \mathrm{~cm}$ flooding did not affect vegetative growth, grain yield, root length and root weight of rice plants. In addition, harvest index did not declined in W3 treatment (Fig. 6c). But W4 treatment significantly reduces $\mathrm{HI}$ and might affects nutritional accumulation in grains (Singh and Bhattacharyya, 1989). However the water use efficiency increased in W3 treatment was significantly higher than other treatments due to efficient use of fresh water for the rice cultivation. These results indicated that LWI did not affect yield and yield parameters of rice plants.

\section{Conclusion}

Previous findings from water saving system showed that the soils are exposed to longer drying condition that possibly imbalance nutrients in soil. However, in this low water input techniques, where the soils are exposed to saturation to $1 \mathrm{~cm}$ flooding, maintain phytoavailability of nutrients in soil. Moreover, low water inputs performed similar to the control, which did not impair plant physiological and yield parameters of rice. Hence, it could be concluded that low water input treatment sustain rice production without interfering soil health and environment. This result is particularly suitable for the Malaysian condition but the intense justification of nutrients interaction, genes up-regulation and antioxidant activities in rice plants will be needed for further documentation for the effectiveness of low water input for sustainable rice production.

\section{Materials and Methods}

\section{Plant Materials}

Two pre-germinated seeds of MR219 of the Malaysian rice variety were sowed in each pot.

\section{Experimental design and water management}

An experiment was conducted under a rain shelter of the research farm of Universiti Sultan Zainal Abidin, Malaysia. So, the rainwater was considered as zero (0) and water needed for land preparation was not considered. Rice plants were cultivated in a pot measuring $30 \mathrm{~cm}$ diameter $\mathrm{x} 40 \mathrm{~cm}$ height placed under the rain shelter. Pots were filled with soil brought from KETARA rice research area at Besut, Terengganu leaving $5 \mathrm{~cm}$ free from the top of the pot. Two holes were made in the body of pots; one at $0 \mathrm{~cm}$ and the other at $1 \mathrm{~cm}$ above the soil level. There were four treatments, namely, W1 (control treatment; continuously flooding at $5 \mathrm{~cm}$ above ground), W2 (continuously flooding at $1 \mathrm{~cm}$ above ground), W3 (continuously saturated condition) and W4 (water was applied at $5 \mathrm{~cm}$ depth when soil moisture declined to the field capacity) were arranged according to the completely randomize design with five replications. An ECHO soil moisture sensor placed in the soil to determine the field capacity of the soil. During flowering stage, $5 \mathrm{~cm}$ flooding water was maintained to initiate pollination and at the ripening stage, all pots were kept without standing water to hasten ripening rate.

\section{Fertilizer application}

Urea fertilizers $\left(\mathrm{N}\right.$ at $110 \mathrm{~kg} \mathrm{ha}^{-1}$ ) with three splits, triple super phosphate $\left(\mathrm{P}_{2} \mathrm{O}_{5}\right.$ at $\left.60 \mathrm{~kg} \mathrm{ha}^{-1}\right)$ and muriate of potash $\left(\mathrm{K}_{2} \mathrm{O}\right.$ at $\left.60 \mathrm{~kg} \mathrm{ha}^{-1}\right)$ as basal, were applied according to Jahan (2004). Compound fertilizer (12: 12: 15) at $250 \mathrm{~kg} \mathrm{ha}^{-1}$ was applied at 50 and 75 days after sowing as stated by Jahan (2016).

\section{Determination of nutrients in soil extracts, soil redox potential, soil $\mathrm{pH}$ and electrical conductivity}

A PVC tube fixed with a porous ceramic cup was inserted into the soil and soil extracts were collected at different weeks during rice cultivation and then analysed for nutrients $(\mathrm{N}, \mathrm{P}, \mathrm{K}, \mathrm{Ca}, \mathrm{Mg}, \mathrm{Zn}, \mathrm{Cu}, \mathrm{Fe}$ and $\mathrm{Mn}$ ) using atomic absorption spectrophotometer and auto analyzer A portable Mettler Toledo $\mathrm{pH}$ meter attached to a redox and a $\mathrm{pH}$ electrode was used to measure the soil redox potential (Eh) and the soil pH (Sarwar and Khanif, 2005b). The electrical conductivity (EC) was measured using a direct soil EC meter (Nozulaidi et al., 2015). Electrodes were calibrated before use. Five replicates were maintained for each parameter.

\section{Measurement of Chl content and Chl fluorescence}

Chlorophyll content was measured using SPAD meter as per 
Khairi et al. (2015). Chlorophyll fluorescence (minimal and maximal fluorescence), quantum yield ( $\mathrm{Fv} / \mathrm{Fm}$ ), coefficients of photochemical fluorescence quenching (qp and ql), parameters of non-photochemical quenching (qn and NPQ), the yield of non-regulated energy dissipation of PSII [Y(NO)], the value of the efficient quantum yield of PSII $\{\mathrm{Y}(\mathrm{II})\}$ and yield of regulated energy dissipation of PSII $\{\mathrm{Y}(\mathrm{NPQ})\}$ were quantified by using a portable JUNIOR PAM fluorometer (Walz, Germany) as described in the manual JUNIOR PAM fluorometer attached with a WinControl3 PAM software. Five replicates were maintained for each parameter.

\section{Measurement of relative water content, light- and photochemical- related parameters}

The fresh weight (FW) of leaves was taken immediately after detached from the plants, incubated in water for 24 hours and then turgid weight (TW) was measured. Dry weight (DW) was measured after the leaf was dried in an oven at $60{ }^{\circ} \mathrm{C}$ for $24 \mathrm{~h}$. The relative water content (RWC) was measured using the following formula (Jahan et al., 2016; Chelah et al., 2011).

RWC $(\%)=(\mathrm{FW}-\mathrm{DW}) /(\mathrm{TW}-\mathrm{DW}) \mathrm{X} 100$.

Internal $\mathrm{CO}_{2}(\mu \mathrm{mol} / \mathrm{mol})$ were measured using a portable gas exchange fluorescence system (CI-340 Handheld Photosynthesis System) according to the manual. The 2nd uppermost leaf was used to measure different gas exchange parameters. Leaf temperature was measured using an infrared thermometer (Fluka, USA) between 11:00 am and 1:00 pm. Five replicates were maintained for each treatment.

\section{Measurement of yields and yields parameters}

The numbers of tiller and panicle per pot were recorded at maturity. The differences of grain yield among treatments were noted. Filled grains and total grains per panicle were counted after filled grains were separated using a salt solution. WUE was measured using the grain yield divided by the amount of water applied, which was determined by a measurement cylinder (Khairi et al., 2015). Harvest index was measured as the ratio of grain weight to the dry weight of the total above ground crop (Khairi et al., 2015).

\section{Statistical analysis}

Student's t-test was employed to evaluate the significance of the differences between the mean values. MS Excel software (Microsoft Corporation) was used for the t-test analysis. P values $<0.05$ were considered statistically significant.

\section{Acknowledgement}

This work was supported by the PRPUM fund project (CG010-2014), FRGS funding (FRGS/2/2014/ STWN03/UNISZA/02/1) and the Faculty of Bioresources and Food Industry, Universiti Sultan Zainal Abidin, Terengganu, Malaysia.

\section{References}

Ariffin T (1998) Kegawatan ekonomi dan pengeluaran beras negara: Satu penilaian semula. Agromedia. 4: 4-9.

Bailey S, Mann NH, Robinson C, Scanlan DJ (2005) The occurrence of rapidly reversible non-photochemical quenching of chlorophyll-a fluorescence in cyanobacteria. FEBS Lett. 579: $275-280$
Barber J (2006) Photosystem II: an enzyme of global significance. Biochem Soc Trans. 34: 619-631.

Bois JF, Couchat PH, Lasceve G (1985) Relationships between transpiration and photosynthesis during a water stress. Acta Hort. 171: 297-314.

Bouman B (2012) Does rice really use too much water? Global rice science partnership http://irri.org/blogs/bas-bouman-s-blog-global-rice-science-par tnership/does-rice-really-use-too-much-water Accessed on 19 Nov 2016

Bruinsma J (2009) The resource outlook to 2050: By how much do land, water use and crop yields need to increase by 2050 . Proceedings of the Expert Meeting on How to Feed the World in 2050, Food and Agriculture Organization of the United Nations, Rome.

Chelah MBK, Nordin MBM, Isa MM, Khanif YM, Jahan MS (2011) Composting increase BRIS soil health and sustain rice production on BRIS soil. Sci Asia. 37: 291-295.

Cicerone RJ, Oremland RS (1988) Biogeochemical aspects of atmospheric methane. Global Biogeochem Cycles. 2: 299-327.

Connell WE, Patrick WH (1969) Reduction of sulfate to sulfide in waterlogged soil. Soil Soc Am Proc 33: 7-11.

De Datta SK (1981) Principles and practices of rice production. Wiley, New York.

De Datta SK, Mikkelsen DS (1985) Potassium nutrition of rice. In: R.D. Munson, M.E. Sumner and W.D. Bishop, Editors, potassium in agriculture. American Society of Agronomy, CSSA, SSSA, Madison, WI, pp. 665-699.

Fan MS, Jiang RF, Zhang FS, Lü SH, Liu XJ (2008) Nutrient management strategy of paddy rice-upland crop rotation system. Chinese J Appl Eco. 19: 424-432.

FAO (2006) World agriculture: towards 2030/2050. Food and Agriculture Organization of the United Nations, Rome.

Foyer CH, Harbinson J (1999) Relationships between antioxidant metabolism and carotenoids in the regulation of photosynthesis. In The Photochemistry of Carotenoids, eds Frank HA, Young AJ, Britton G, Cogdell RJ. Kluwer Academic Publishers, Dordrecht, The Netherlands, pp 305325 .

Godshalk GL, Wetzel RG (1978) Decomposition in the littoral zone of lakes. In: Good RE, Whigham DF \& Simpson RL (Eds) Freshwater Wetlands. Academic Press, NY, pp. 131-143.

Goudie A (2006) Global Warming and Fluvial Geomorphology. Geomorphology. 79: 384-394.

Gupta RK, Ladha JK, Singh J, Singh G, Pathak H (2007) Yield and phosphorus transformations in a rice-wheat system with crop residue and phosphorus management. Soil Sci Soc Am J. 71: 1500-1507.

Hoekstra AY, Chapagain AK (2008) Globalization of water: sharing the planet's freshwater resources. Blackwell Publishing, Malden, MA, USA.

Hou AX, Chen GX, Wang ZP, Van Cleemput O, Patrick Jr WH (2000) Methane and Nitrous Oxide Emissions from a Rice Field in Relation to Soil Redox and Microbiological Processes. Soil Sci Soc Ame J. 64: 2180-2186.

Inani $N$, Nozulaidi $M$, Khairi $M$, Abdulkadir AB, Jahan MS (2015) Glutathione functions on physiological characters of corn plants to enhance Mn-induced corn production. Pertanika J Trop Agric Sci. 38: 509-518.

IRRI (2001) Annual report for 2000. International Rice Research Institute Los Baños, Philippines.

Ishizuka Y (1965) Nutrient uptake at different stages of growth. In: The Mineral Nutrition of the Rice Plant. O. G. Santos, ed. John Hopkins Press. Baltimore, MD, pp. 199-217.

Jahan MS (2004) Rice production under different water inputs. $\mathrm{PhD}$ Thesis. Department of Land Management, Faculty of Agriculture, Universiti Putra Malaysia.

Jahan MS (2016) Rice production under different water inputs. LAP LAMBERT Academic Publishing.

Jahan MS, Nordin MNB, Che Lah MKB, Khanif YM (2013a) Effects of water stress on rice production:bioavailability of 
potassium in soil. J Stress Physiol Biochem. 9: 97-107.

Jahan MS, Khanif YM, Sinniah UR (2013b) Effects of low water input on rice yield: Fe and Mn bioavailability in soil. Pertanika J Trop Agric Sci. 36: 27-34.

Jahan MS, Khanif YM, Sinniah UR, Nozulaidi MBN, Khairi MBCL (2012) Bioavailability of soil nitrogen in low water input rice production. J Sustain Sci Manage. 7: 207-212.

Jahan MS, Nozulaidi M, Khairi M, Mat N (2016) Light-harvesting complexes in photosystem II regulate glutathione-induced sensitivity of Arabidopsis guard cells to abscisic acid. J Plant Physiol. 195: 1-8.

Jahan MS, Nozulaidi M, Khandaker MM, Afifah A, Husna N (2014) Control of plant growth and water loss by a lack of light-harvesting complexes in photosystem-II in Arabidopsis thaliana ch1-1 mutant, Acta Physiolog Planta. 36: 1627-1635.

Jahan MS, Ogawa K, Nakamura Y, Shimoishi Y, Mori IC, Murata Y (2008) Deficient glutathione in guard cells facilitates abscisic acid-induced stomatal closure but does not affect light-induced stomatal opening. Biosci Biotechnol Biochem. 72: 2795-2798

Kato Y, Satoshi H, Akiniko K, Abe J, Urasaki K, Yamagishi J (2004) Enhancing grain yield of rice (Oryza sativa L.) under upland conditions in Japan. 4th International Crop Science Congress, Brisbane, Australia.

Keizrul A, Azuhan M (1998) An overview of water resources utilization and management in malaysia. Proceeding on "local communities and the environment II". Environment Protection Society Malaysia, Petaling Jaya, pp. 24-25.

Khairi M, Nozulaidi M, Afifah A, Jahan MS (2015) Effect of various water regimes on rice production in lowland irrigation. Aus J Crop Sci. 9: 153-159.

Kim JD, Jugsujinda A, Carbonell-Barrachina AA, DeLaune RD, Patrick Jr. WH (1999) Physiological functions and methane and oxygen exchange in Korean rice cultivars grown under controlled soil redox. Bot Bull Acad Sin. 40: 185-191.

Kura-Hotta M, Satoh K, Katoh S (1987) Relationship between photosynthesis and chlorophyll content during leaf senescence of rice seedlings. Plant Cell Physiol. 28: 1321-1329.

Morales LA, Vázquez EV, Paz-Ferreiro J (2011) Spatial and temporal variability of Mehlich-1 extractable Fe, Mn and Zn over a rice field as a function of lime amendment. J Stoch Environ Res Risk. 25: 1039-1048.

Mosier AR, Mohanty SK, Bhadrachalam A, Chakravorti SP (1990) Evolution of dinitrogen and nitrous oxide from the soil to the atmosphere through rice plants. Biol Fert Soils. 9: 61-67.

Müller P, Li XP, Niyogi KK (2004) Update on photosynthesis: non-photochemical quenching. a response to excess light energy. Plant Physiol. 125: 1558-1566.

Munirah N, Jahan MS, Nashriyah M (2015a) N-acetylcysteine and $\mathrm{Zn}$ regulate corn yield. Sci Asia. 41: 246-250.

Munirah N, Khairi M, Nozulaidi M, Jahan MS (2015b) The effects of zinc application on physiology and production of corn plants. Aus J Basic Appl Sci. 9: 362-367.

Narteh LT, Sahrawat KL (1999) Influence of flooding on electrochemical and chemical properties of West African soils. Geoderma. 87: 179-207.

Neue HU, Wassmann R, Kludze HK, Wang B, Lantin RS (1997) Factors and processes controlling methane emissions from rice fields. Nutr Cycling Agroecosyst. 49: 111-117.

Nozulaidi M, Khairi M, Jahan MS (2015) Effects of different salinity levels on rice production. Aus J Basic Appl Sci. 9: 524-530.

Oki T, Kanae S (2006) Global hydrological cycles and world water resources. Science. 313(5790): 1068-1072.

Okuma E, Jahan MS, Munemasa S, Ogawa K, Watanabe-Sugimoto M, Nakamura Y, Shimoishi Y, Mori IC, Murata Y (2011) Negative regulation of abscisic acid-induced stomatal closure by glutathione in Arabidopsis. J Plant Physiol. 168: 2048-2055.

Olk DC, Cassmon KG, Carlson RM (1995) Kinetics potassium fixation in Vermiculite soil under different moisture regimes.
Soil Sci Soc Am J. 59: 423-429.

Patrick Jr. WH, Mahaparta IC (1968) Transformation and availability to rice of nitrogen and phosphorus in waterlogged soils. Adv Agron. 20: 323-359.

Ponnamperuma FN (1972) The Chemistry of submerged soils. Adv Agron. 24: 29-96.

Ponnamperuma FN (1977) Behaviour of minor elements in paddy soils. IRRI research paper series-8. Los Banos, Philippines, p.7.

Ponnamperuma FN (1984) Effects of flooding on soils. In Flooding andPlant Growth (ed. Kozlowski, T.). Academic Press, New York, pp. 9-45.

Ponnamperuma FN, Attanandana T, Beye G (1973) Amelioration of three acid sulfate soils for lowland rice. Proceeding on International Symposium On Acid Sulfate Soils. International Institute Land Reclamation and Improvement, Wageningen, The Netherlands, p 391-406.

Randall SA, Thornber P, Fiscus E (1977) Water stress effects on the content and organization of chlorophyll in mesophyll and bundle sheath chloroplasts of maize. Plant Physiol. 59: 351-353.

Sariam O, Khanif YM, Zahrah T (2002) Rice growth and nitrogen uptake as influenced by water management. Malaysian J Soil Sci. 6: 1-11.

Sarwar MJ, Khanif YM (2005a) Techniques of water saving in rice production in Malaysia. Asian J Plant Sci. 4: 83-84.

Sarwar MJ, Khanif YM (2005b) Low water rice production and its effect on redox potential and soil pH. J Agron. 4: 142-146.

Sarwar MJ, Khanif YM (2005c). The Effect of Different Water Levels on Rice Yield and $\mathrm{Cu}$ and $\mathrm{Zn}$ Concentration, J. of Agronomy., 4:116-121.

Sarwar MJ, Khanif YM, Syed Omar SR, Sinniah UR (2004) The effect of different water regimes on yield and bioavailability of Phosphorus in rice production in Malaysia. Malaysian J Soil Sci. 8: 53-62.

Schubert H, Andersson M, Snoeijs P (2006) Relationship between photosynthesis and non-photochemical quenching of chlorophyll fluorescence in two red algae with different carotenoid compositions. Marine Biol. 149: 1003-1013.

Sheela KR, Alexander VT (1996) Physiological response of rice varieties as influenced by soil moisture and seed hardening. Indian J Plant Physiol. 38: 269-271.

Singh KN, Bhattacharyya HC (1989) Direct seeded rice. Oxford and I.B.H. Publication, New Delhi, 31.

Syuhada N, Jahan MJ (2016) Glutathione functions on physiological characters to increase copper-induced corn production. Russ Agril Sci. 42: 5-10.

Syuhada N, Jahan MS, Nashriyah M, Khairi M, Nozulaidi M, Razali MHB (2014) Application of copper increased corn yield through enhancing physiological functions. Aust J Basic Appl Sci. 8: 282-286

Thiyagarajan TM, Selvaraju R (2001) Water-saving rice cultivation in India. Procceeding of an international workshop on water-saving rice production system at Nanjing University, China, pp. 15-45.

Vandeleur RK, Mayo G, Shelden MC, Matthew-Gilliham M Kaiser BN, Tyerman SD (2009) The role of plasma membrane intrinsic protein aquaporins in water transport through roots: diurnal and drought stress responses reveal different strategies between isohydric and anisohydric cultivars of grapevine. Plant Physiol. 149: 445-460.

Wang Z, Delaune RD, Masscheleyn PH, Patrick Jr WH (1993) Soil redox and $\mathrm{pH}$ effects on methane production in a flooded rice soil. Soil Sci Soc Am J. 57: 382-385.

Yoshida S (1981) Fundamentals of rice crop science International Rice Research Institute, Los Banos, Philippines.

Yu KW, Wang ZP, Vermoesen A, Patrick WH, Van Cleemput O (2001) Nitrous oxide and methane emissions from different soil suspensions: Effect of soil redox status. Biol Fertil Soils. 34: 25-30. 